\title{
TOUCH AND AMERICAN RELIGIONS
}

\begin{abstract}
The sense of touch plays an important role in many American religious practices. Yet dismissals of touch as an inferior mode of perception and reliance on textual sources that ignore touch have shaped research agendas. This essay identifies theories articulated by philosophical phenomenologists, students of ritual and performance studies, historians and anthropologists of art and architecture, neuroscientists, and feminist scholars that envision touch as a unique mode of gaining knowledge about the world and oneself and stimulating ethical behavior by working directly on the emotions to motivate empathetic, compassionate concern for others. The essay suggests how touch-oriented theories can aid the development of research areas in American religions where scholars have already begun fruitful explorations of tactility: studies of religious embodiment and ritual and of pain and its alleviation through divine healing or Complementary and Alternative Medicine (CAM).
\end{abstract}

\section{GRASPING THE SENSE OF TOUCH}

The sense of touch is foundational to human, indeed to all animal, experience and influences religious life. Touch is at once a physiologically based perception, grounded in receptor neurons concentrated in the skin, and evokes affective and metaphorical meanings—as in a "touching” experience, getting "in touch,” or "reach out and touch someone” to express relational connection and empathy. Touch incorporates the sensitivity of the skin, proprioception or bodily position, vestibular perception or sense of balance, kinaesthetics or bodily movement, and haptics or manipulation of objects to gain knowledge about the world (Paterson 2007). The sense of touch allows humans to discriminate between hot and cold, dry and moist, pressure and 
release, heavy and light, hard and soft, viscous and brittle, rough and smooth, coarse and fine (Chrétien 2004). Touch can be pleasant or painful, healing or harming, intimate or violent, voluntary or involuntary. An ability to touch or be touched by others implies both separation and communication; touch is reciprocal-as one touches, one is touched.

Scholars of American religions have paid relatively little attention to the sense of touch as a mode of understanding religious beliefs and practices. This is unsurprising given that Western scholarly traditions have long denigrated touch as the most primitive and animal-like of the senses. Plato disparaged all the senses, but especially touch, as deceiving. Aristotle's De Anima (c. 350 B.C.) hierarchically arranges the senses, positioning vision at the top and touch at the bottom. Although Aristotle expressed ambivalence-celebrating human touch as supremely discriminating and as contributing to intellectual and moral development, yet belittling touch as metaphysically and morally inferior to other senses_-Western philosophers and theologians emphasized Aristotle’s negative ideas (Synnott 1991; Classen 1993). The Christian ascetic tradition, bolstered by Cartesian mind-body dualism, devalued the body and its senses as dangerous to the soul. As Enlightenment thinkers, notably John Locke, esteemed sensory experience as the path through which correct ideas enter the mind, the sense of sight gained preeminence (Schmidt 2000). Sight has often been figured as the highest sense, associated with the mind, masculine rationality, and truth, while touch has been envisioned as the lowest sense, connected to the body, emotion, deception, feminine and racial eroticism, and physical and moral contamination (Holler 2002).

American religious historians, until the mid-twentieth century, scrutinized intellectual and doctrinal history, while ignoring the body and its senses as irrelevant to understanding religious knowledge or experience. The turn in the study of American religions to the human 
body, emotions, lived religion, practices, and material culture has partially unsettled hierarchical assumptions about the corporeal senses. Leigh Schmidt's Hearing Things (2000) includes a few tantalizing references to tactility — the touch of sound vibrations and a memorable description of a farmer nuzzling his Bible. Mark Smith’s How Race is Made (2006) incorporates brief references to how touch contributed to white Southern identity as distinct from that of black people. David Chidester (2000) wrote one of the few essays that focuses on touch in American religious history. One reason scholars still have relatively little to say about touch is that many work with textual sources, which are well suited to communicating ideas, whereas touch communicates on a pre-verbal, pre-visual, emotional level that is difficult to articulate in words, but which nevertheless shapes religious dispositions and potentially motivates ethical actions.

The importance of touch to American religions_-and the need for scholarly analysis_-is if anything increasing in the modern world. Sociologist John Naisbitt (1982, p. 48) argues that the "escalation of high technology within a society creates a compensatory need for 'high touch.’” People participate in disembodied practices - for instance replacing face-to-face interactions with the Internet-without satisfying their fundamental human need to touch and be touched. Phenomenologist Mark Paterson (2007, p. 149) points to an "underlying need for connection, a yearning for contact and proximity in a potentially isolating and alienating world, perhaps exacerbated by the emphasis on hollow consumerism in late capitalism.” Scholars have an opportunity to analyze how Americans have used tactile religious practices to meet the need for meaningful touch and to explore the implications for understanding American religions.

This essay identifies theories of touch that might be engaged as scholars encounter the prevalence of tactile sensations and practices in their consideration of several interrelated fields in American religions: religious embodiment and ritual and pain and its alleviation through 
divine and alternative healing. Many research opportunities remain for scholars willing to feel their way through diverse literatures and artifacts to take touch seriously as a mode of analyzing American religions.

\section{THEORETICAL RESOURCES}

A crucial insight articulated by phenomenologists like Emmanuel Lévinas (1987) and Edith Wyshograd (1980) and ritual theorists like Catherine Bell (1992) and Talal Asad (1993) is that touch is a primary, pre-cognitive mode by which people gain knowledge of the world and themselves. Because touch works on an emotional, affective level, tactile input such as that gained through bodily actions and disciplines shapes religious dispositions more powerfully than do belief systems cultivated solely through seeing and hearing—senses which, in lived experience, are not hierarchically arranged but overlap with the senses of touch, taste, and smell (Merleau-Ponty 1962; Sullivan 1990; Schechner 2003; Verrips 2002). The implication for the study of religions is that scholars need to pay more attention not only to what religious practitioners do with their bodies, but also to how the body feels and what tactile sensations communicate about people’s environments and identities. Because women and people of color have often been associated with the body, the "lower" senses, and emotions, there is opportunity to use such assumptions as a starting point for exploring touch as a unique epistemological tool, one that calls attention to the body's material, gendered, racialized relation to the world and to frequently unequal power relationships (Classen 1998; Irigaray 1993; Smith 2006; Manning 2007).

Drawing upon Christian and Buddhist philosophies, historians and anthropologists of art and architecture as well as neuroscientists and feminist theorists have suggested that touch may play a special role in motivating ethical behavior, including empathetic, compassionate action to 
promote the good and alleviate the suffering of others. By such theories, desire for pleasurable sensations and avoidance of pain are strongly motivational; touch works directly on the emotions to attract or repel. Architecture historian Rebekah Smick (2003) emphasizes a neglected strand in Aristotle, developed by Thomas Aquinas, that pleasurable sensations provide experiential knowledge of God's love and goodness thereby motivating virtuous action. Drawing on Buddhist mindfulness philosophy, neuroscientist James Austin (1998) and feminist Linda Holler (2002) argue that touch cultivates an ability to respond emotionally to one’s surroundings and, by becoming more aware of the consequences of one’s own actions moment-by-moment, to seek to alleviate the pain and suffering of others. Thus, the association of women and people of color with touch and emotion can be used, for instance, to subvert gender and racial hierarchies by linking tactility with ethical behavior.

\section{EMBODIED RELIGIOUS PRACTICES}

Scholars of American religions have recently turned their attention to embodied religious practices—selection of clothing, bodily postures and movements in prayer and worship rituals, and regulation of human sexuality. Researchers have made important strides toward making visible tactile practices that have long been overlooked, yet there have been relatively few efforts to interpret how tactile practices feel, what differentiates knowledge of self and world gained through touch from knowledge otherwise acquired, or how touch might or might not motivate ethical behavior. What difference does it make that people perform religion rather than simply believing it? Religion scholars might draw upon research in such fields as neuroscience, robotics, and anthropology (Barsafou 2005; Foerst 1994; Csordas 2002; Coakley 1997) suggesting that bodily rituals provide metaphors for desired mental and spiritual states thereby 
helping to produce them. Art and architecture historians (James 2004; Pallasmaa 1996) offer insights into how embodied practices provide assurance of religious ideas, apparently revealing spiritual truths that might otherwise remain hidden, thereby using the senses to transcend merely corporeal experience.

Colleen McDannell (1995, p. 2) was among the first American religious historians to observe how sensory experiences not only reflect, but also “bring about religious values, norms, behavior, and attitudes.” Religious objects worn—and thus felt—next to the body remind the wearer of beliefs while engaged in daily activities and solidify community identity. For example, Mormon undergarments are invisible to outsiders but can be felt by practitioners. Orthodox Jewish men wear yarmulkes (skull caps) and tallits (prayer shawls). Pre-Vatican II Catholics wore scapulas, small pieces of cloth blessed by a priest and placed on the shoulders under clothing, to attain spiritual merit and secure protection from danger. Today, members of certain Catholic religious orders wear distinctive clothing, and some lay Catholics pin medals of saints to their underwear when reporting for radiation therapy. Protestants in need of healing might also wear blessed prayer cloths or secretly sew them into clothing of non-Christian family members (Orsi 1996; Brown 2006).

Prayer and worship rituals often involve tactile practices. Sunni Muslims kneel five times daily facing Mecca, drawing the palms over the face and crossing the shoulders as if anointing oneself. Dance has played a prominent role in the worship of Native American traditionalists, African-American Pentecostals, and Anglo-American Episcopalians (McDannell 2002; Maffly-Kipp et al. 2006). By contrast to Word-oriented Protestants, Roman Catholics assume that God communicates inward grace to the human soul through external signs and instruments, especially the sacraments, in ways that are perceptible through all the bodily senses 
(McDannell 1995). During the Eucharist, Catholics feel the wafer on their tongues as they receive the body of Christ. Catholics understand the oil they feel applied to their foreheads during the sacrament of Anointing of the Sick to reflect the Holy Spirit's healing presence. Catholics touch the ground with their knees while genuflecting to honor the presence of Christ; with their hands, they make the sign of the cross to recall the death of Jesus; they finger rosary beads while meditating on scenes and stories from the life, death, and resurrection of Christ. During the first half of the twentieth century, American Catholics developed a tactily-rich devotional culture involving the use of holy oil and water, and prayer cards and statues that might be touched as well as seen (Orsi 1996). The liturgical reforms of the Second Vatican Council (1962-1965) relegated much of devotional Catholicism to a secondary position as it emphasized the Eucharist. Marian devotions, which involve tactile practices such as carrying medallians or figurines, revived in America in the 1980s through the influence of recent immigrants from Latin America. For some Haitian immigrants who practice both Catholicism and Vodou in cities like Brooklyn, or Cuban immigrants who combine Catholicism with Santería in cities such as Miami, the touch of holy water or images—obtained from a shrine pilgrimage or purchased at a botánica — might evoke reverence both for Catholic saints and African deities (Orsi 2005; Tweed 1997).

The religious significance of human sexuality has only begun to receive scholarly attention (Griffith 2008), although most religions ascribe meanings to the pleasurable tactile sensations of sexual intercourse. Many Native American traditions have viewed menstruating women as possessing heightened spiritual powers that could also make their intimate or casual touch contaminating; most groups approved sex outside marriage or with multiple marriage partners (Mays 2004). Judaism, Christianity, and Islam all prohibit sexual contact among the 
unmarried. Members of Catholic religious orders must be celibate-making clerical sexual abuse charges appear to Catholics doubly problematic; even for married Catholics sexual intimacy without procreation is proscribed. Sex between marital partners is often viewed positively, as reflected in the title of one popular evangelical marriage manual: Intended for

Pleasure: Sex Technique and Sexual Fulfillment in Christian Marriage (Wheat \& Wheat, 1997). Married orthodox Jews abstain from sexual intercourse during a woman’s menstrual cycle, but positively view marital sex at other times as a gift from God that is religiously significant as representing God's marriage to his people (Harris 1985). In other religious traditions, for instance Tantric Hinduism, sexual touch is celebrated as corresponding with penetrating into the Supreme Consciousness (Skora 2007).

\section{PAIN}

The aspects of human tactile sensation that have elicited the greatest attention from scholars of American religions are physical pain and efforts to ameliorate it, through divine or alternative healing. The question that has occupied scholars is how the meanings of pain and pleasure have changed as technologies made it possible to alleviate some but not all pain. The body's ability to sense pain is grounded in touch-stimulated receptor neurons in the skin and within the body that transmit information to the brain which processes it as pain. The physical sensation of pain is often associated with mental and emotional states of suffering-fear of disease, terror induced by torture, or shame of sexual violation. Even as touch between bodies is reciprocal, the sensation of pain, as Elaine Scarry (1985) notes, is unsharable—it feels undeniably certain to the person experiencing it, yet cannot be confirmed by anyone else. The narrative that emerges from research on pain (Glucklich 2001; Curtis 2007) is that prior to (and beyond) the mid-nineteenth century, Protestant and Catholic clergy in America often identified 
pain as chastisement for sin or as a means of sharing in the sufferings of Christ. Developments in anesthesia made freedom from pain seem attainable, yet provoked resistance from those who worried that artificial insensitivity to pain either violated God's will or impeded the restoration of harmony between individuals and nature. As many lay Protestants revolted against Calvinism, they re-envisioned pain as morally evil, sent by the devil rather than God, and rejected severe medical regimens in favor of the body’s “natural” restorative powers. Meanwhile, biomedicine reinterpreted pain not as a spiritual malady the cause of which demands explanation, but merely as a physical sensation.

As David Chidester explains (2005, p. 26), Americans came to regard as both physically beneficial and morally good that which "feels good” or "provides pleasurable sensations along the tactile register of the body." Thus, it is out of tactile experience that desires to avoid pain, achieve pleasure, and satisfy a longing for connection with human or spiritual others constitute a driving force in American religions, creating a culture that scholars have dubbed "therapeutic" (Rieff 1966). Scholars might bring into conversation theories that have linked pain-avoidance and pleasure-seeking with ethical awareness and compassion for others with theories that have evaluated American therapeutic impulses as tending toward self-absorbed consumerism and insensitivity to others' feelings. Two cultural movements that have gained significant popular followings over the past one-hundred fifty years, divine healing and Complementary and Alternative Medicine, are founded upon the assumptions that feeling is believing and that which is effective in relieving pain is morally good. Scholarship might probe the implications of an assumptive framework that makes efficacy in relieving pain a premium standard for determining what is real and evaluating ethical meanings. Research might ask whether certain ways of touching, being touched, or certain types of tactile sensations are more or less communicative or 
tend more toward empathy or unconcern for others. How does it matter that women and people of color have played prominent roles in healing movements?

\section{DIVINE HEALING}

Christians have used touch in praying for healing since the first century. European historians assessed the "royal touch," or the belief that kings could cure diseases like scrofula (Bloch 1973). David Edwin Harrell’s study (1975) of healing revivals of the 1940s-50s was one of the first scholarly treatments of American healing practices. More recent scholarship has focused on the 1860s-1930s, or offered ethnographic descriptions of contemporary practices. Scholarship effectively calls attention to the prevalence of tactile practices in healing rituals, but does less to investigate why this matters. Do rituals do or mean something different depending on whether or what kind of touch or tactile sensations are involved or who is doing the touching? What do shifts in tactile practices and meanings ascribed to touch reveal about American religions? Do experiences of human or divine touch motivate ethical behavior?

The nineteenth-century Faith Cure and twentieth-century Word of Faith movements (in common with Mind Cure movements like Christian Science, although the groups disagreed theologically) embraced an epistemology that mistrusted the senses, especially touch, as evidence of healing. The “acting faith” model required that believers act upon the Bible’s promises of healing, if necessary ignoring “sensory knowledge” (Curtis 2007). By contrast, most American Pentecostal and Charismatic Christians today esteem the sense of touch-more than sight (sometimes envisioned as the opposite of faith) or medical documentation—as evidencing healing. Evangelists encourage those receiving prayer to confirm their healings by trying to do something they could not do before while feeling whether it causes pain. 
When a self-conscious divine-healing movement first developed in the mid-nineteenth century, Protestants, suspicious of Catholic sacramentalism, hesitantly emulated actions described in the Bible such as anointing and laying hands on the sick, insisting that such measures were merely ordinances that expressed obedience and encouraged faith rather than sacraments efficacious in themselves. With the rise of Pentecostalism in the 1900s, a new language of power led Protestants to envision the anointing of the Holy Spirit as a tangible, transferable substance communicable through the touch of a hand or an anointed handkerchief, or through written texts such as a Bible or periodical containing healing promises (Opp 2005). A small contingent of Pentecostals validated the truth of biblical promises through such tactile practices as handling poisonous snakes (Orsi 2005). Healing evangelists such as Oral Roberts spent countless hours laying hands on the sick as they waited in healing lines, or praying for all the sick present to be healed while they placed their own hands on diseased body parts or on the chair or television in front of them as a "point of contact” for releasing faith. Roberts claimed to know that the power of the Lord was present to heal when he felt a sensation of heat and tingling in his right hand. By contrast, healing evangelist Kathryn Kuhlman refused to lay hands on the sick, insisting that one could receive a healing touch from the Holy Spirit by sitting in the anointed atmosphere of her miracle services (Brown 2008). Divine healing practices today have largely been “democratized,” to borrow sociologist Margaret Poloma’s (2003) term, as lay Christians envision their own touch as communicating healing power. Vineyard founder John Wimber encouraged laity to exercise the charismatic gift of the "word of knowledge" —one of nine gifts of the Holy Spirit enumerated in I Corinthians 12. Significantly, this gift is understood primarily as providing tactile, rather than verbal, revelation. According to Wimber, Christians can get a word of knowledge in any one of five ways: one can feel it, know it, read it, see it, or 
say it. Yet the vast majority of times that Charismatics claim to have a word of knowledge they feel it as a sympathetic pain in their own bodies.

Scholars of American religions have not kept pace with participants in theorizing the role of touch in healing practices. Self-reflective and articulate divine-healing leaders, including the Catholic Francis MacNutt (1974) and the Protestant Randy Clark (2006) have written extensively about the role of touch in healing. For MacNutt and Clark, the Holy Spirit's anointing flows through the touch of the human hand, causing both the person praying and the person receiving prayer to feel heat, a gentle current, or more rarely an overpowering electrical force. In developing the concept of "soaking prayer," MacNutt adopts the modern analogy of radiation therapy to argue that the laying on of hands in prayer is cumulative in its benefits as pray-ers facilitate a transfer of the life of Christ into sick individuals, over time shrinking tumors and killing germs. Clark uses the term “impartation” to describe the global transference of healing anointing through touch—spreading revival fires from Argentina (1980s-1990s) to the Toronto Blessing (1994-2006), to Brazil, the U.S., Mozambique, and dozens of countries.

Divine healing practices reflect not only a desire to feel pain relief but also a longing to feel God's touch. By the late nineteenth century, as science eroded traditional grounds of religious certainty, people searched for evidence of modern-day divine activity in the physical world (Mullin 1996). Pentecostals typically place a high value on sensory experiences that indicate the power, presence, and concern of God-for instance feelings of heat, electricity, or shaking. God's touch is perceived as mediated through human touch, perhaps including falling backwards into the arms of “catchers”-empathetic community members who symbolize, as Thomas Csordas notes (2002), the body of Christ, when one is “slain” or "rests” in the Spirit. By contrast, Word-oriented evangelical critics of Pentecostalism consider sensory experience an 
untrustworthy guide to truth (Hunt et. al. 1997). Assuming that phenomenological similarity constitutes evidence of ontological equivalence, critics worry that instead of signifying a touch from God, tactile experiences indicate psychological suggestion or transference of occult power or imply illicit sexual overtones.

\section{COMPLEMENTARY AND ALTERNATIVE MEDICINE}

Touch-based healing rituals are by no means restricted to Christianity, but date back to ancient times and can be found in cultures around the world. Anthropologists studying healing rituals in diverse cultures note the importance of massage, “sucking,” and herbal baths (Katz 1982; Dow 1986; Rasmussen 2006). Scholarship on Complementary and Alternative Medicine (CAM) has been concerned with describing the nature of touch-based practices and the theories motivating them; as with other research areas, opportunities exist to probe the varieties of tactile expressions and sensations and how these matter to understanding American religions. Is touch experienced differently depending on who does the touching and whether touch is associated with empathetic intentions to heal or envisioned as connecting individuals with universal energy?

Do and, if so, how do specific tactile practices or experiences motivate ethical behavior?

Early European immigrants in America often consulted Native American and enslaved African healers, despite warnings of religious contamination expressed by Christian clergy. As medical technologies made it possible for Americans to enjoy longer, healthier lives at the expense of personalized care, healthcare consumers patronized medical doctors to prescribe medications and perform procedures, while paying alternative practitioners to satisfy their longing for empathetic, thus therapeutic touch—_touch as not only feeling, but as feeling-with" (Paterson 2007, p. 13). Although medical doctors today typically spend seven minutes with each 
patient, CAM appointments often involve thirty to fifty minutes of touch between practitioner and patient (Lake \& Spiegel 2007). Usage rates of touch-oriented alternative therapies remained relatively constant throughout the twentieth century (estimated by surveys at 34\% in 1924 and 1990), but the cultural position of CAM shifted from periphery to center as the holistic healthcare movement of the 1970s cultivated interest in consumer choice and renewed concern for “natural” remedies. (Whorton 2002, p. 223).

As with divine healing, some of the most articulate theorists of touch in CAM are practitioners. Because Christian clergy have often devalued the human body and its senses, many Americans of European descent, as historian Robert Fuller argues (2001), have envisioned God as irrelevant to daily needs—such as healing—and looked elsewhere for therapies, appropriating resources from Native American, Taoist, Buddhist, Hindu, and diverse metaphysical traditions that place a higher value on the sensing body. For CAM practitioners, sensations such as temperature modulations, tingling, or pressure demonstrate the reality of “subtle” energy undetectable to modern scientific instruments.

The assumption unifying diverse therapies is the existence of universal life-force or vital energy — termed qi in traditional Chinese medicine (e.g. acupuncture, qigong, T’ai Chi Ch'uan), $k i$ in Japanese traditions (e.g. Reiki, shiatsu massage), prana in Ayurvedic medicine (e.g. yoga), vital force in homeopathy, or Innate Intelligence in chiropractic — that flows through the universe and permeates the human body (Whorton 2002). Blockages or imbalances in the flow of energy are believed to cause illness. Healing practices involve opening blockages and restoring equilibrium in the flow of energy through the body's energy channels (chakras and nadis/meridians), by means of direct physical touch and/or manipulation of energy fields by oneself or others. Yoga presumes that controlled breathing, bodily postures, and meditation 
withdraw the senses from the everyday world and regulate the flow of prana. In T'ai Chi Ch'uan, the controlled use of force, in such movements as hitting, lifting, and throwing, is envisioned as balancing yin and yang and opening the flow of qi. Chiropractic involves manual spinal manipulations thought to be efficacious because they unblock the flow of Innate Intelligence. Acupuncture and acupressure involve using needles or human hands to apply stimulating, but generally painless, touch to an acupoint, which because of the flow of qi, is envisioned as affecting physically distant bodily organs. The ingestion or external application of physical substances is thought efficacious in moving energy into proper balance. In homeopathy, the tactile procedures of grinding, shaking, and diluting plant substances are believed to unleash the vital force of the plants. In aromatherapy, inhaling or absorbing plant oils through the skin is thought to infuse the body's subtle energy system with the essence or spirit of the plants. Curanderos perform purifications (limpias) in which they pass objects such as herbs or eggs over the body to absorb negative vibrational energy, or manipulate energy by administering herbs in teas or baths or transmitting mental vibrations; ritual objects from Catholicism, such as crucifixes, holy water, incense, or oils, are believed to emit vibrations and fragrances that touch ambient energy and please the spiritual world, which is envisioned as possessing sensory capacities (Trotter \& Chavira 1997).

Therapeutic Touch, developed in the 1970s by NYU nursing professor Dolores Krieger and Theosophist Dora Kunz, has attracted widespread interest (Lippincott Williams \& Wilkins, 2003). Despite the name, skin-to-skin contact is incidental. Practitioners—often nurses working in hospitals — envision themselves as touching and manipulating energy fields. Placing their hands two to four inches from the patient's skin and feeling for areas of energy imbalancesensed as heat or cold, tingling, or pressure-practitioners use sweeping motions to push energy 
from congested areas. Practitioners believe that thoughts, emotions, and intuitions—such as conscious, compassionate intent to heal—-touch and direct energy. Similarly, the popular Amish healer Solomon Wickey touches patients mentally, “sending a coded signal to the body via silent thought” (Naugle 2005, p. 273). Externally applied qigong therapy (EQT) likewise uses mental intentions to manipulate qi (Lake \& Spiegel 2007).

\section{CONCLUSION}

Scholars of American religions have produced growing literatures exploring tactile practices related to religious embodiment and ritual and interpretations and relief of pain. As scholarship exploits the realization that religion is as much about what people experience through their bodies as what they believe, researchers can draw upon theories of touch as uniquely providing knowledge about the world and oneself that potentially stimulates ethical behavior. For students of American religions struggling to contribute to a field that has generated abundant scholarship, attending to tactility may offer just the right touch of a fresh mode of handling their subjects.

\section{REFERENCE LIST}

Asad, T. Genealogies of Religion: Discipline and Reasons of Power in Christianity and Islam. Baltimore: Johns Hopkins University Press.

Austin, J. H. (1998) Zen and the Brain: Toward an Understanding of Meditation and Consciousness. Cambridge, MA: MIT Press.

Barsafou, L. W., Barbey, A. K., Simmons, W. K. \& Santos, A. (2005). Embodiment in Religious Knowledge, Journal of Cognition and Culture 5(1-2), pp. 14-58.

Bell, C. (1992) Ritual Theory, Ritual Practice. New York: Oxford University Press. 
Bloch, M. L. B. (1973). The Royal Touch: Sacred Monarchy and Scrofula in England and France. London: Routledge \& K. Paul.

Brown, C. G. (2006). From Tent Meetings and Store-Front Healing Rooms to Walmarts and the Internet: Healing Spaces in the United States, the Americas, and the World, 1906-2006, Church History, 75(3), pp. 631-47. (2008). Healing Words: Narratives of Spiritual Healing and Kathryn Kuhlman’s Uses of Print Culture, 1947-1976. In: CL Cohen \& PS Boyer, eds., Religion and the Culture of Print in Modern America. Madison: University of Wisconsin Press, 2008.

Chidester, David. (2000). Haptics of the Heart: The Sense of Touch in American Religion and Culture, Culture and Religion, l(1), pp. 6l-84. . (2005). Authentic Fakes: Religion and American Popular Cuiture. Berkeley: University of California Press.

Chrétien, J. (2004). The Call and the Response, AA Davenport (trans.). New York: Fordham University Press.

Clark, R. (2006). There is More!: Reclaiming the Power of Impartation. Mechanicsburg, PA: Global Awakening.

Classen, C. (1993). Worlds of Sense: Exploring the Senses in History and across Cultures. London: Routledge. (1998). The Color of Angels: Cosmology, Gender, and the Aesthetic Imagination. New York: Routledge.

Coakley, S., ed. (1997). Religion and the Body. New York: Cambridge University Press. Csordas, T. (2002). Body/Meaning/Healing. New York, NY, Palgrave Macmillan. 
Curtis, H. D. (2007). Faith in the Great Physician: Suffering and Divine Healing in American Culture, 1860-1900. Baltimore: Johns Hopkins University Press.

Dow, J. (1986). The Shaman's Touch: Otomí Indian Symbolic Healing. Salt Lake City: University of Utah Press, 1986.

Foerst, A. (1994). God in the Machine: What Robots Teach Us about Humanity and God. New York: Dutton.

Fuller, R. C. (2001). Spiritual, but not Religious: Understanding Unchurched America. Oxford: Oxford University Press.

Glucklich, A. (2001). Sacred Pain: Hurting the Body for the Sake of the Soul. New York: Oxford University Press.

Griffith, R. M. (2008). The Religious Encounters of Alfred C. Kinsey, Journal of American History, 95(2): pp. 349-77.

Harrell, D. E. (1975). All Things Are Possible: The Healing and Charismatic Revivals in Modern America. Bloomington: Indiana University Press.

Harris, L. (1985). Holy Days: The World of a Hasidic Family. New York: Simon \& Schuster.

Holler, L. (2002). Erotic Morality: The Role of Touch in Moral Agency. New Brunswick, NJ: Rutgers University Press.

Hunt, S., Hamilton, M. \& Walter, T. (1997). Charismatic Christianity: Sociological Perspectives. New York: St. Martin's Press.

Irigaray, L. (1993). An Ethics of Sexual Difference. Ithaca, NY: Cornell University Press.

James, L. (2004). Senses and Sensibility in Byzantium, Art History, 27(4), pp. 522-37.

Katz, R. (1982). Boiling Energy: Community Healing among the Kalahari Kung. Cambridge: Harvard University Press. 
Lake, J. \& Spiegel, D. (2007). Complementary and Alternative Treatments in Mental Health Care. Washington, DC: American Psychiatric Publications.

Lévinas, E. (1987). Language and Proximity. In: A Lingis (trans.), Collected Philosophical Papers. Boston: Kluwer Academic.

Lippincott Williams \& Wilkins. (2003). Nurse's Handbook of Alternative \& Complementary Therapies. Philadelphia: Lippincott Williams \& Wilkins.

MacNutt, F. (1974). Healing. Notre Dame, IN: Ave Maria Press.

Maffly-Kipp, L. F., Schmidt, L. E. \& Valeri, M. R. (2006). Practicing Protestants: Histories of Christian Life in America, 1630-1965. Baltimore: Johns Hopkins University Press.

Manning, E. (2007). Politics of Touch: Sense, Movement, Sovereignty. Minneapolis: University of Minnesota Press.

Mays, D. (2004). Women in Early America: Struggle, Survival, and Freedom in a New World. Santa Barbara, CA: ABC-CLIO.

McDannell, C. (1995). Material Christianity: Religion and Popular Culture in America. New Haven: Yale University Press. , ed. (2002). Religions of the United States in Practice, vol. 2. Princeton, NJ: Princeton University Press.

Merleau-Ponty, M. (1962). The Phenomenology of Perception, trans. C Smith. London: Roudedge \& K. Paul.

Mullin, R. B. (1996). Miracles and the Modern Religious Imagination. New Haven: Yale University Press.

Naisbitt, J. (1982). Megatrends: Ten New Directions Transforming Our Lives. New York: Warner Books. 
Naugle, J. (2005). Solomon's Touch: The Life and Work of Solomon J. Wickey. Bloomington, IN: AuthorHouse.

Opp, J. W. (2005). The Lord for the Body: Religion, Medicine, and Protestant Faith Healing in Canada, 1880-1930. Ithaca, NY: McGill-Queen's University Press.

Orsi, R. A. (1996). Thank You, St. Jude: Women's Devotion to the Patron Saint of Hopeless Causes. New Haven: Yale University Press. (2005). Between Heaven and Earth: The Religious Worlds People Make and the Scholars Who Study Them. Princeton, NJ: Princeton University Press.

Pallasmaa, J. (1996). The Eyes of the Skin: Architecture and the Senses. London: Academy Editions.

Paterson, M. (2007). The Senses of Touch: Haptics, Affects, and Technologies. New York: Berg. Poloma, M. M. (2003). Main Street Mystics: The Toronto Blessing and Reviving Pentecostalism. Walnut Creek, CA: AltaMira Press.

Rasmussen, S. J. (2006). Those Who Touch: Tuareg Medicine Women in Anthropological Perspective. DeKalb: Northern Illinois University Press.

Rieff, P. (1966). The Triumph of the Therapeutic: Uses of Faith after Freud. New York: Harper \& Row.

Scarry, E. (1985). The Body in Pain: The Making and Unmaking of the World. New York: Oxford University Press.

Schechner, R. (2003). Performance Theory. New York: Routledge.

Schmidt, L. E. (2000). Hearing Things: Religion, Illusion, and the American Enlightenment. Cambridge: Harvard University Press. 
Skora, J. M. (2007). The Pulsating Heart and its Divine Sense Energies: Body and Touch in Abhinavagupta's Trika Śaivism, Numen, 54(4), pp. 420-58.

Smick, R. (2003). Touch in the Hypnerotomachia Poliphili: The Sensual Ethics of Architecture. In: ED Harvey, Sensible Flesh: On Touch in Early Modern Culture. Philadelphia: University of Pennsylvania Press.

Smith, M. (2006). How Race is Made: Slavery, Segregation, and the Senses. Chapel Hill: University of North Carolina Press, 2006.

Sullivan, L. E. (1990). Body Works: Knowledge of the Body in the Study of Religion, History of Religions 30(l), pp. 86-99.

Synnott, A.. (1991). Puzzling over the Senses: From Plato to Marx. In: D Howes (ed.), The Varieties of Sensory Experience: A Sourcebook in the Anthropology of the Senses. Toronto: University of Toronto Press.

Trotter, R. T. \& Chavira, J. A. (1997). Curanderismo: Mexican American Folk Healing. Athens: University of Georgia Press.

Tweed, T. A. (1997). Our Lady of the Exile: Diasporic Religion at a Cuban Catholic Shrine in Miami. New York: Oxford University Press.

Verrips, J. (2002). “Haptic” Screens and Our “Corporeal Eye,” Etnofoor, 15(1/2), pp. 21-47.

Wheat, E. \& Wheat, G. (1977; 1997). Intended for Pleasure. Third.edition. Grand Rapids, MI: Revell.

Whorton, J. C. (2002). Nature Cures: The History of Alternative Medicine in America. New York: Oxford University Press.

Wyschograd, E. (1980). Doing Before Hearing: On the Primacy of Touch. In: F Laruelle (ed.), Textes Pour Emmanuel Lévinas. Paris: J.-M. Place. 